\title{
Characteristics of CD44 alternative splice pattern in the course of human colorectal adenocarcinoma progression
}

\author{
Balázs Bánky ${ }^{1,2^{*}+}$, Lívia Rásó-Barnett ${ }^{1,3 \dagger}$, Tamás Barbai ${ }^{1}$, József Tímár ${ }^{1,4}$, Péter Becságh ${ }^{1}$ and Erzsébet Rásó ${ }^{1,4}$
}

\begin{abstract}
Background: CD44 is considered as ' $a$ ' metastasis associated gene, despite the fact that it is an umbrella term for a group of molecules produced from a single gene by alternative splicing. However, little consideration is given to the above in the literature of colorectal carcinomas as well as other tumour types, leading to confusion and contradictory results about its possible role in tumour progression.

Methods: We compared the CD44 alternative splice pattern (ASP) of three genetically different human colorectal cancer cell lines (HT25, HT29, HCT116) using a series of PCR reactions and next- generation sequencing method, as well as identified a colorectal adenocarcinoma specific CD44 ASP. This ASP was further investigated in terms of its qualitative and quantitative stability in our experimental iso- and xenograft mouse models for colorectal cancer progression. A complex preclinical experimental set-up was established to separately test the different steps of tumour progression and the role of tumour microenvironment, respectively, focusing on the role of 'CD44' in this process.

Results: We managed to present a colorectal cancer-specific CD44 ASP, which remained unchanged from cell lines throughout primary tumour formation and metastatic progression. Furthermore, we report a unique roster of all expressed CD44 variant isoforms characteristic to colorectal cancer. Finally, on quantitative assessment of the variable exons v3 and v6, higher co-expression levels were found to be characteristic to metastatically potent tumour cells.

Conclusion: Particular CD44 variant isoforms seem to act as "metastasis genes" via tumour microenvironment-driven shifts in $v 3$ and $v 6$ expressions. However, this function may just affect a minority of tumour subclones. This fact and the huge potential number of different CD44 splice variants that can contain v3 and v6 domains can explain incoherence of clinical studies regarding functional asessment of CD44 variants, as well as diminish the chances of using CD44 variants for predictive purpose.
\end{abstract}

Keywords: CD44, v3, v6, Alternative, Splicing, Metastasis, Colorectal, Cancer, Microenvironment

\section{Background}

In developed countries, colorectal cancer (CRC), or rather its progression to metastatic disease, accounts for $25 \%$ of tumour deaths [1]. Characterising the metastases associated processes is therefore of crucial importance for identifying ways of earlier and more sensitive diagnosis, more defined prognosis, and possibly in the selection of patients for targeted therapies.

\footnotetext{
* Correspondence: bankybalazs@yahoo.com

${ }^{\dagger}$ Equal contributors

'2nd Institute of Pathology, Semmelweis University, Üllői út 93., 1091,

Budapest, Hungary

${ }^{2}$ St Borbála Hospital, Department of Surgery and Vascular Surgery, Dózsa Gy. út 77., 2800, Tatabánya, Hungary

Full list of author information is available at the end of the article
}

A variety of genes have been described and extensively investigated in the literature as key candidates in the tumorigenesis and progression of colorectal carcinoma, including APC, p53, K-ras, BRAF, DCC, MSH, EGFR, SFK, TGFR2, SMAD4, etc. [2-5].

Each individual step of the metastatic cascade is the result of complex molecular interactions, regulated by several already identified and/or unidentified genes [6]. One of the candidates of key importance has been CD44. In fact, it is one of the most investigated molecules in the metastatic process of several malignancies [7-13], among them that of colorectal cancer [14-16].

\section{Biomed Central}


CD44 was first described to be a lymphocyte homing receptor [17]. The role of CD44 was later proven in fetal arteriogenesis [18], as well.

Furthermore, expression and function of various isoforms of CD44 were detected in chronic inflammatory diseases (rheumatoid arthritis, ulcerative colitis, resolution of lung inflammations, etc.) [19-21].

A number of studies demonstrated the expression of CD44s (standard version) on most tissue types of epithelial origin (stomach mucous membrane, small intestinal mucosa, prostate, ductal epithelium of breast, skin, hair follicules, transitional cell membrane of utgenital tract) [22-26]. Regarding colonic mucosa, immunohistochemical examinations demonstrated that CD44s (identified with antibody against the standard region of the molecule) is located at the level of basal crypts, similar to the "intestinal stem cells" of the small intestine sitting between Paneth-cells [27-29]. This means that proliferative cells of colonic mucosa, as well as cells in the basal segment of differentiation zone are able to provide CD44s expression, while differentiated mucosal cells don't show membrane positivity on immunostaining any more [30]. This fact gains special importance when considering the change of 'CD44' expression characteristics from the normal, the dysplastic and the malignant colorectal tissues [31].

Additionally, and probably not independently form the above mentioned findings, recent studies demonstrated 'CD44' as a potential tumour stem cell marker (in colorectal, gastric and pancreatic adenocarcinoma, as well as breast cancer and other cancers) [32-39].

With the presence of CD44 protein in so many tissues, consideration has to be given to its physiological and pathological functions.

'CD44' has a variety of biological functions such as cell-cell, cell-ECM interactions, tumour cell migration $[40,41]$ or even chemoresistance $[16,41-50]$. This multitude of representations and functions is less surprising when considering that through its 9 variable exons (v2-v10), hundreds of different isoforms can be transcribed and translated from the single CD44 gene resulting in a mixture of glycoproteins with potentially different functions [51-53]. Talking about 'CD44' and studying its 'over expression' therefore is rather debatable and not as straight-forward as it was previously thought. A basic understanding and consideration of alternative splicing should be warranted when dealing with this versatile gene. For the same reason, when using probes (i.e. primers or antibodies) against the standard region of CD44 (CD44s), one will detect a mixture of isoforms as they all share the same standard region $[54,55]$.

Determining the role of 'CD44' is further complicated by the difficulties to identify all the isoforms potentially characterizing certain cell or tissue types. The trend is to focus on the expression of a single variable exon, which, of course, will only show the summation of isoforms containing the exon in question. However, these isoforms might only share a single variable exon, therefore they can be of different functions. In addition, several other CD44 variant isoforms can be present within the same cell, adding further functions to 'CD44' [56-59]. Furthermore, different cells of a tumour can express various, possibly different sets of CD44 isoforms. As most of our tests examine a group of cells from the tissue at the same time, the results are summated, failing to represent the cell-to-cell differences in details [6]. In colorectal carcinoma the most studied variant exons / protein domains are v3 and v6.

CD44v3 is the heparane-sulphate proteoglycane domain of CD44, however, the v3-containing isoforms of CD44 have hyaluronate binding potential and may contain a chondroitin-sulphate proteoglycan domain as well. Consequently, CD44v3 can bind different heparin-binding growth factors (GF), such as HBEGF, VEGF, HGF, $\beta F G F$, KGF and amphiregulin [60,61].

CD44v6 functions as receptor of HGF/SF cooperating with c-met [61,62], regulating EMT and taking part in the positive feedback loop of K-ras activation driving both Ras signal transduction pathway and CD44-splicing machinery $[3,63,64]$. Additionally, this is the domain most frequently found to be associated with metastatic phenotype in the literature [65].

Unsurprisingly, the studies of detecting 'v3' and ' 66 ' under different experimental and clinical settings do not lead to coherent results, and can even be contradictory. This also can be observed in the literature regarding colorectal cancer [14,66-71].

Recently, characteristic CD44 isoform patterns of different normal tissue types have been described in the literature [24-26,72,73] and our earlier studies described CD44 isoform patterns characteristic of different tumour types, respectively (data publication in progress, RásóBarnett et al.). Most of the literature agrees that 'CD44' plays an important role during tumour progression based on 'overexpression' of specific variant regions containing isoforms at mRNA and/or protein level. However, no data is available concerning the pattern of CD44 isoforms and its modulation during tumour progression. Our previous study on CD44 alternative splice patterns showed no qualitative change of the melanoma specific 'CD44-fingerprint', while the expression level of all isoforms uniformly increased during the metastatic process (data publication in progress, Rásó-Barnett et al.).

The aim of our research was to find answers to the following two questions: (1) Is there a colorectal carcinoma specific CD44 isoform expression combination like to one identified in human melanoma? If there is such pattern, is it qualitatively / quantitatively stable 
during tumour progression? (2) What is the background of the incoherent quantitative results on the expression of the most investigated v3 and v6 variable exons / protein domains?

To answer the first question, we designed primer pairs covering the entire variable region (primers A-B, see Methods) for our quantitative and qualitative PCR reactions. The expressed, i.e. transcribed CD44 isoforms were identified using direct sequencing and nextgeneration sequencing.

Due to the large number of potential isoforms, we used a series a PCR reactions to create the CD44 fingerprint, a simple, easy to handle representation of the expressed CD44 isoforms. We used this fingerprint to track the changes of CD44 expression during tumour progression [41,55,74-76].

To answer our second question, we designed a complex experimental animal model to examine the functional role $\mathrm{CD} 44 \mathrm{v} 3$ and $\mathrm{CD} 44 \mathrm{v} 6$ containing isoforms play in metastasis formation. The main question was whether or not there is a change in the expression of these variable exons that could be associated to the metastatic process of human colorectal carcinoma. We implanted the same colorectal cancer cell population orthotopically to form real metastases in liver, as well as heterotopically. We performed two types of heterotopic implantation: the first involved subcutaneous implantation into permissive and non-permissive hosts, the second was direct implantation into the spleen so that the implanted cells could directly colonize the liver. The latter method created a new type of secondary tumour, which albeit is in the same localization as the liver metastases of the true metastatis model, has not been through the metastatic cascade. This experimental setup allowed to functionally differenciate between phases of metastatic process and host related changes, regarding the expression activity of the examined variable CD44 exons.

\section{Results}

Colorectal adenocarcinoma (CRC) specific CD44 alternative splice pattern (ASP)

Human colorectal cell lines (HT25, HT29, HCT116) could be characterized by the dominance of five bands on agarose gel electrophoretograms (ELFO) when examining the variant region of CD44 with a primer pair testing and overlapping the entire variant region (Primer $\mathrm{A}$ - Primer B) Figure 1, Figure 2B. This PCR reaction would theoreticaly amplify each transcribed CD44 variant isoform. In three of the five bands (372 bp, $564 \mathrm{bp}$, 768 bp) we identified a particular CD44 isoform by direct sequencing. Even these bands, as well as those bands which were not definitely identified by direct sequencing, potentially 'hide' more, different isoforms. None of the dominant PCR producs that were identified by direct sequencing represented v3 or v6 containing isoforms. Next-generation sequencing (NGS) performing allele specific high performance sequencing managed to identify further isoforms including some of those which contain v3/v6 exon products. This method managed to differentiate more isoforms hidden behind the same ELFO bands. Furthermore, eight more isoforms with very low expression activities were identified by this sensitive method. These isoforms do not appear on the qualitative picture of ELFO. (Surprisingly, NGS provided evidence to the fact that CD44 isoform without any variant exons (CD44v0) does exist, in spite of the widely accepted theory that v1 variant exon is constitutively expressed) Figure 1.

Additionally, we identified a number of definitely expressed CD44 isoforms by four further PCR sets performed with primer pairs directly designed onto exons v3 and v6 (Primer pairs A-D, A-E, C-B, C-E) Figure 1, Figure 2A. Primers designed for particular exons (e.g. v3 or v6) gave evidence of that exon being transcribed, as a minimal premise of amplification on PCR. Some of these isoforms did not appear among the products of the reaction 'A-B', either for some quantitative or particular PCR reaction technical reasons. Precise knowledge of exon lengths enabled us to calculate the expression of further isoforms according to product sizes in addition to the ones detected by direct sequencing of PCR products. These two methods provided a rich roster of definite and estimated CD44 isoforms which are represented by being isoforms of very similar size.

This way we identified CD44 isoforms expressed in CRC cell lines from a qualitative picture derived from five-primer-pair PCR series covering the entire length of the variable region of CD44 with overlapping sequences. By running the PCR products of the five different primer pair reactions on agarose gel always in the same order, a colorectal cancer specific alternative splice pattern (ASP) could be described for all three human colorectal cell lines (HT29, HCT116 and HT25) Figure 2B.

Colorectal specificity of this CD44-fingerprint is detailed and proven elsewhere (publication in progress, Rásó-Barnett et al.), here we just demonstrate a few samples of CD44 fingerprints of other tumour types, i.e. MCF7 (breast cancer), HT199 (melanoma), A431 (vulvar epidermoid carcinoma), and K562 (myelogenous leukemia) respectively.

After all, there were 26 different CD44 isoforms identified in the qualitative CD44 fingerprint of colorectal cancer, 24 of which were proven by sequencing and only two remained 'estimated/calculated' isoforms Figure 1. However further isoforms can also be present, only hidden behind 'truncated' CD44 isoforms sharing the same truncated part of the whole molecule (i.e. Isoform 14-26 on Figure 1.). 


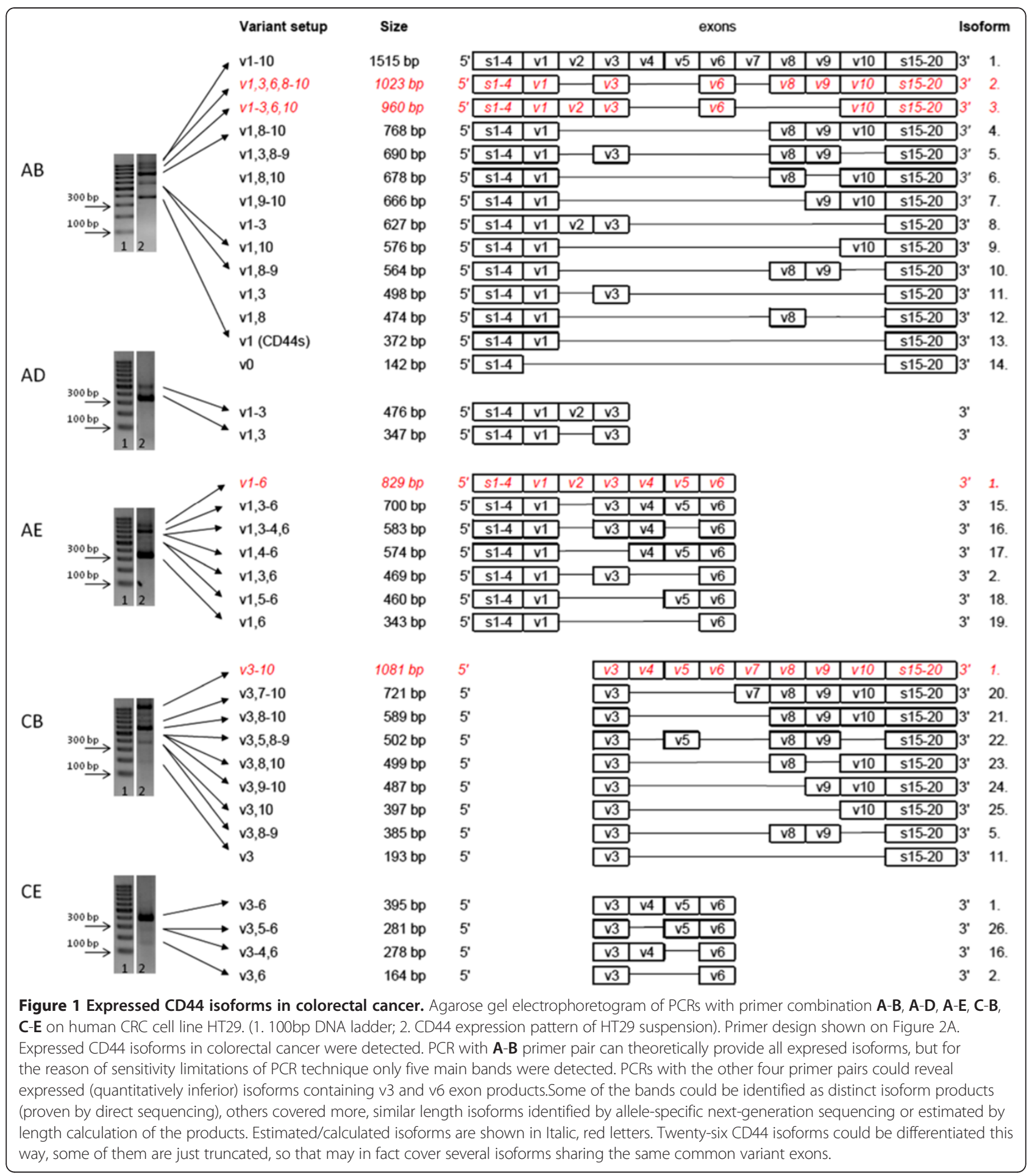

\section{Characterisation and examination of the stability of the colorectal CD44 'fingerprint'}

\section{Comparison of tumours growing in vitro and in vivo}

CD44 pattern of our samples from the xenotransplantation model has proven that the pattern is preserved in vivo the same way it was seen in vitro. ASP of CD44 was found to be highly similar of HT29 cells cultured in vitro as compared to orthotopic primary (colon) or heterotopic primary (spleen, subcutaneously in adult and newborn mice) Figure 2D,E. HT25 and HCT116 cell lines were found to behave the same conservative way, (data not shown). 


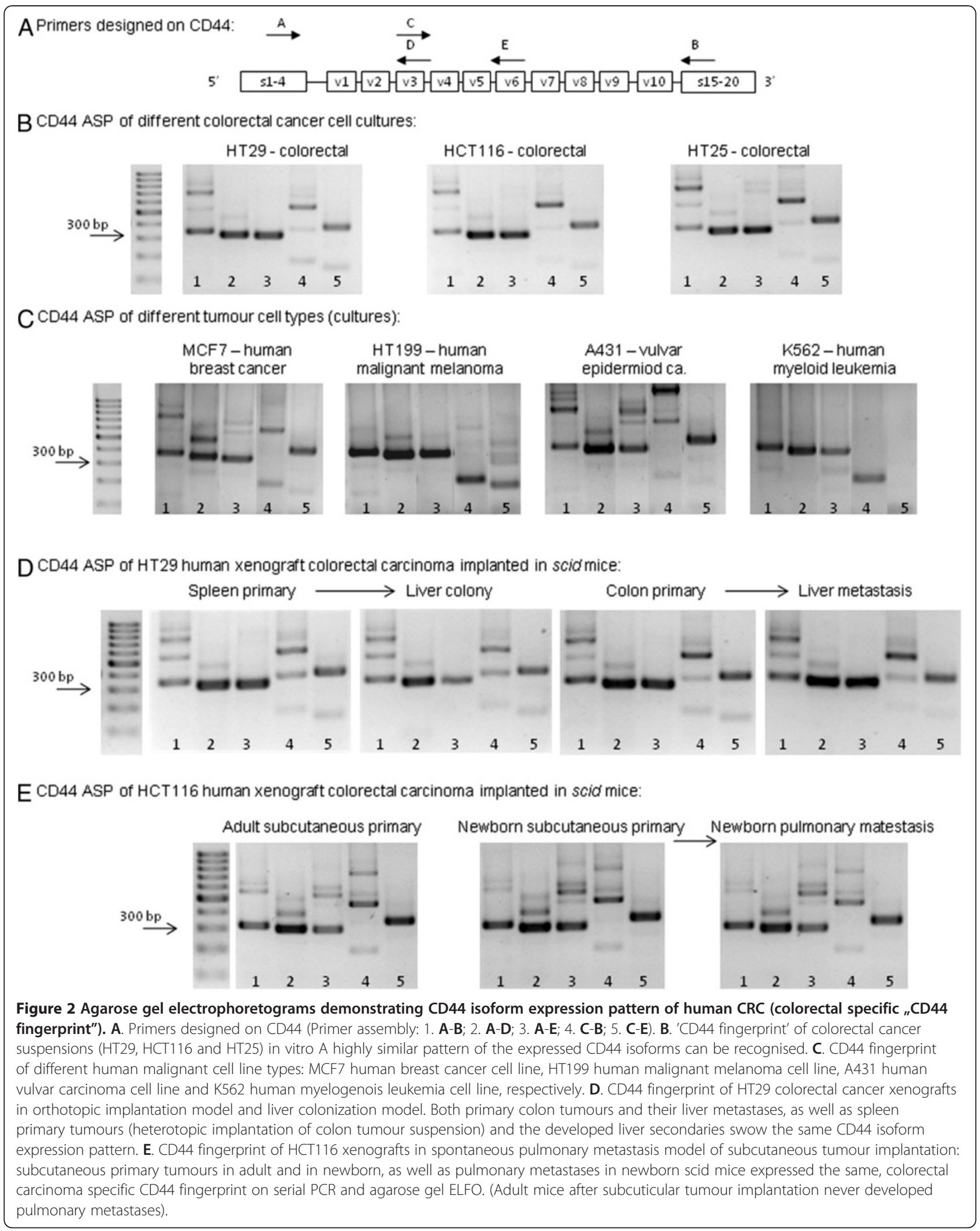




\section{Behaviour of CRC-specific CD44 alternative splice pattern (ASP) during the metastatic process of the tumours}

To determine whether the expression pattern changes during the metastatic process in our xenograft system, we implanted HT29 cell suspension into spleen and orthotopically into large bowel, coecal wall. We then compared the CD44 pattern of the primary tumour and the liver metastasis/colony of the same animal in both models. The pattern was found to be unchanged Figure 2D. Similar, unchanged expression patterns were detected in the other two tumour types, HT25 and HCT116, respectively (data not shown).

In the case of HT29, the heterotopically (subcutaneous) implanted primary tumour showed the exact same pattern as the cell suspension in both the metastatic (newborn) and non-metastatic (adult) host. In metastatic cases (in each newborn animal) pulmonary metastases gave the same ASP, as well Figure 2E. The number of implanted animals in each arm of the model was three, the qualitative expression pttern was overally homogenous. (A total number of 40 animals were transplanted, 28 of them developed metastases, and we used 3-3 animals to check the CD44 fingerprint.)

\section{Quantitative change of certain exons (v3/v6) of the CD44 variable region during tumour progression of colorectal cancer in mice \\ Mouse C26 isograft system}

CD44v3 and CD44v6 expressions of orthotopic (coonic wall) and heterotopic (splenic implantation) primary C26 tumours (four mice in each group), as well as spontaneous liver metastases and liver colonies (from splenic implantation) were compared using real-time PCR Figure 3A. Data indicate that while the expression level of both variable exons were more than one magnitude larger in the liver metastases compared to that of the primary tumour in the orthotopic implantation model (significant differences both on v3 and v6 expression), no significant alteration was detected between the spleen primary and the liver colony. Furthermore, it is remarkable that primary tumours of both systems showed similar expression levels.

\section{Human colon cancer xenografts}

All three implanted human colon cancer lines (HT29, HT25, HCT116) possessed similar metastatic potential in both systems, showing a 50-65\% metastatic rate.

Real time PCR measurement using CD44v3 and CD44v6 exon specific primers showed three different ways of behaviour in the three colorectal cell types. In representative samples we compared the relative CD44v3 and CD44v6 levels of the primary tumours and liver metastases or liver colonies in both systems, similarly to the isograft experiments Figure 3B.
In case of HT29, identically to C26, we detected significantly elevated expression levels in liver metastases after orthotopic implantation compared to the primary tumour of the colonic wall, while both variable exons were expressed at the same level in both the primary splenic tumour and the liver colony of the spleen-liver system. It is also interesting that primary tumours from both localisations showed similar expression levels.

HT25 behaves opposite to Balb/C-C26 isograft system. Primary tumours and metastases both showed identical expression levels in the orthotopic system.In the case of HCT116, the primary tumours provided extremely high CD44v3/v6 expression levels. Liver metastases showed a magnitude lower expression level. Therefore, the third cell line represents a completely different, third pattern of behavior Figure 4A.

\section{Spontaneous lung metastasis xenograft model from subcutaneous implantation}

The same three, genetically different human colorectal cell suspensions (HT25, HT29, HCT116) were implanted into lumbar subcutaneous localization of three-three adult and newborn scid mice. No metastases were formed in the adult animals, while each newborn developed distant lung metastases. CD44v3 and CD44v6 expression levels of non-metastatic adult and metastatic newborn primary tumours were measured. The results from the three examined human xenografts are summarised on Figure 3C.

The difference in v3 and v6 variant expression level between the metastatic newborn and non-metastatic adult primary tumours is clearly demonstrated. The tendency is uniform across all three CRC tumours in this model, showing 2-3 fold higher v3 and v6 expression levels in the newborn than in adult primary tumours, however the difference with three animals in each arm could just reach the level of significance in the case of HCT116 colorectal tumour type.

\section{Discussion}

Despite hundreds of published studies on CD44 within the last two decades, noconsensus opinion has been reached as of today apart from that it plays some role in tumour progression $[69,76]$. One of the possible explanations is that from microarrays to immunohistochemistry, the overwhelming majority of studies fail to take into consideration that ' $\mathrm{CD} 44$ ' is a collection of isoforms generated via alternative splicing of its nine variable exons. Probes, primers and antibodies against the standard region will recognise a pool of different isoforms as they all share the same standard region, and not the isoform itself, which is functionally active and involved in the metastatic process. A good example of this is colorectal adenocarcinoma, where the cells of origin, i.e. 


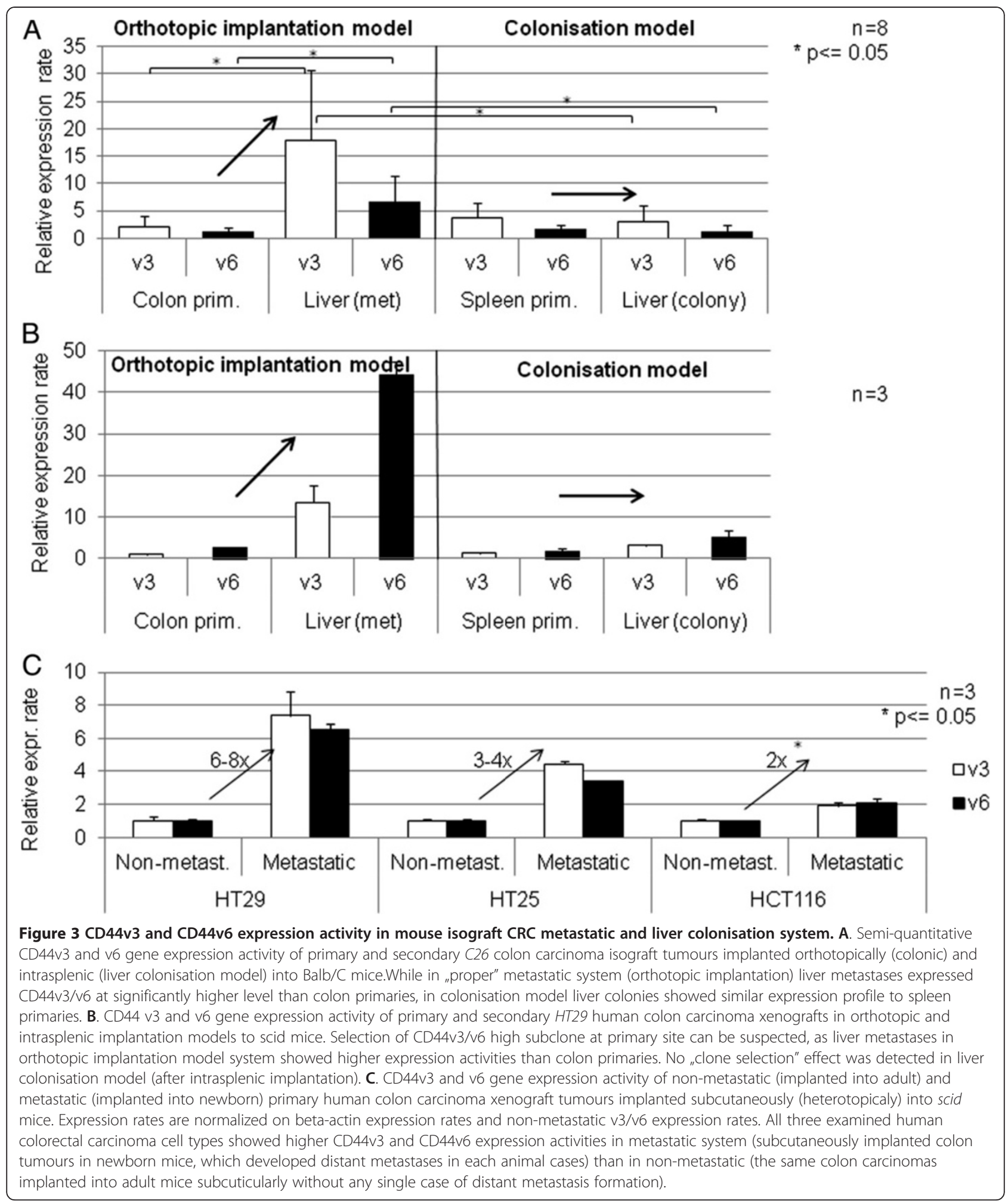

the glandular epithelium of the large bowel, express standard form of CD44 (CD44s), but not variant ones $(\mathrm{CD} 44 \mathrm{v})$, while highly dysplastic colorectal adenomas, primary and metastatic colorectal cancers express a large variety of different-length CD44 isoforms, both on mRNA and protein levels [14,31,44,77-79]. Some of these new CD44 isoforms acquired during malignant transformation contain v3 and v6 domain which add a 


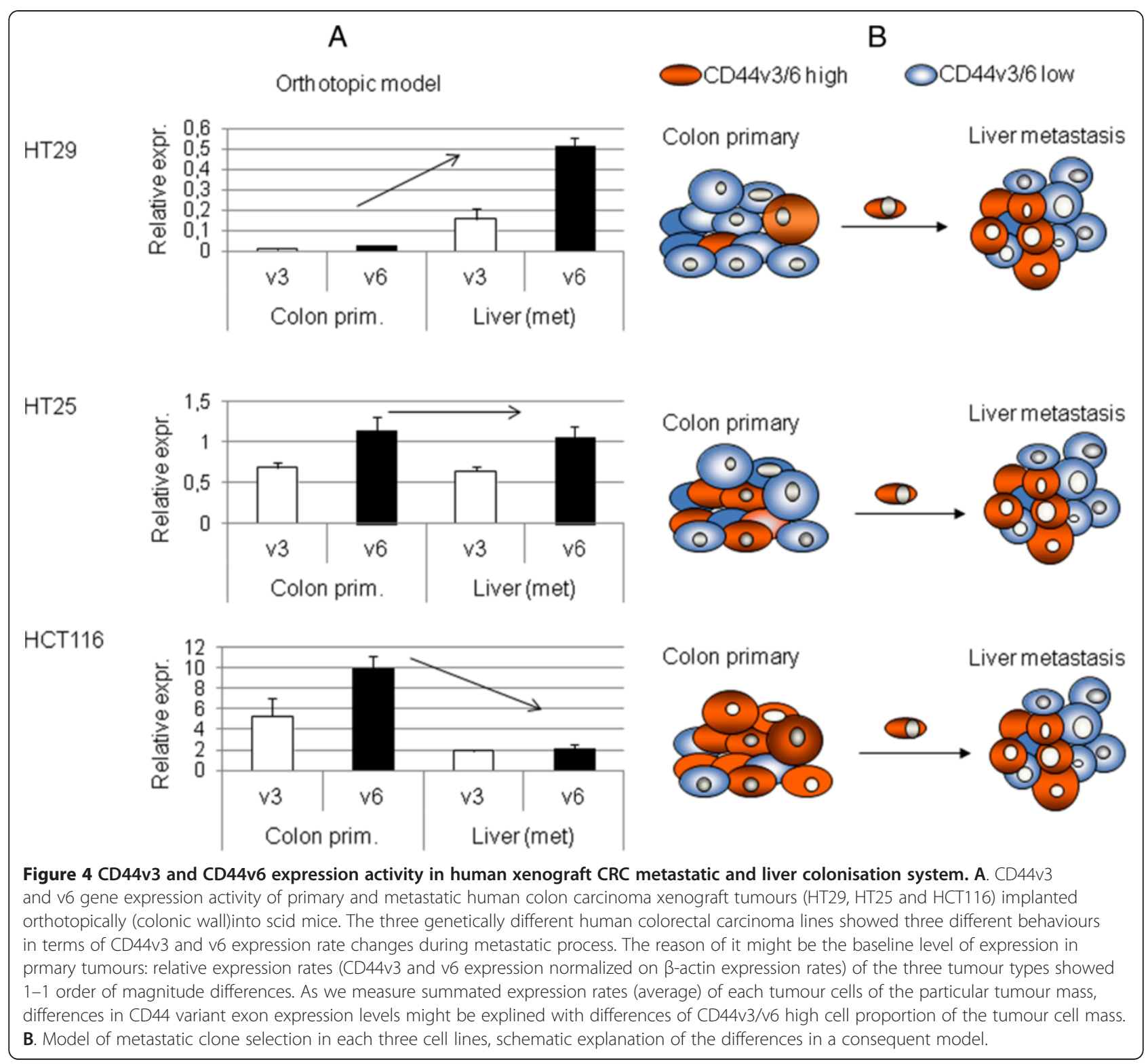

completely different range of functions to the preexisting CD44s functions, as CD44v6 is a co-receptor of the met protein, and CD44v3 is one of the most important presenters of heparin-binding growth factors, such as HGF, the main ligand of Met $[60,62]$. One must also consider that multiple variable regions might be present in a single isoform, adding further functional abilities. It is likely that the molecular interactions of CD44v3 are different from those of CD44v2-v10 variant despite both containing the v3 region, yet they will be 'measured' as a single product when using CD44v3 primers/probes/ antibodies. Again, probes against any particular exons /protein domains od CD44 will demonstrate a wide range of CD44 isoforms, all of which share the same particular exon/domain. Furthermore, most of our tests are performed on mixtures of different tumour tissue elements: these assays work on a conglomerate of tumour cells, stromal cells, their proteins or gene products. Results of these reactions will lways represent some sort of average or summation. This might influence the qualitative expression pisture of distinct gene products of a tumour sample, but certainl will affect quantitative one. Considering this makes it easier to understand the contradictions of the literature.

Our aim was to identify a roster of CD44 isoforms expressed by colorectal cancer to see the extent of complexity we need to face when examining 'CD44'. We also wanted to determine whether a potential "malignant" colorectal adenocarcinoma-specific isoform parttern exists. We then aimed to examine the stability of this 
pattern during tumour progression, i.e. whether it is qualitatively stable or new isoforms become dominant. This was tested in our complex iso- and xenograft experimental animal models. Reproducibility of v3 and v6 changes described in the literature was also tested in our experimental animal models. These models enabled us to separately study steps of tumour progression as well as the role of the tumour microenvironment.

First of all we attempted to identify the expressed isoforms from the qualitative CD44 ASP. We concluded that although not all the possible isoforms are expressed in reality, it is still rather technically impossible to identify the ones that do get expressed.All three attempts of ours on completing the isoform roster were only partially successful: (i) Our A - B primer overlapped the whole CD44 variable region, still just a few "dominant" isoforms could be identified as qualitative PCR products with direct sequencing. Some other isoforms could me identified according to the PCR product length, as well. Further CD44 variants were added by four other PCRs carried out with primer pairs designed onto particular exons of interest (v3 and v6). (ii) Next-generation sequencing theoretically should provide an allele-specific list of all transcribed isoforms. Still we reached limitations of the technique, but managed to identify more, sofar unidentified isoforms. (iii) I our previous publication on similar experimental set-up on melanoma (data under publication, Rásó-Barnett et al., paper accepted) identification attempt of "each" expressed CD44 isoform by cloning was reported to be fruitful, but again far from complete. We feel that the result of CD44 splicing is far richer than the sensitivity and effectivity of today's tests. However, we do not yt know if this complexity of CD44 ASP carries any special functional importance. For now, we need to focus on functional characterization of distinct exons/domains of the complex molecule selectively.

Although the complete CD44 isoform list was not achieved, we identified simplified colorectal adenocarcinoma specific CD44 alternative splice pattern (ASP) which was qualitatively stable across samples from different colorectal cancer cell lines in vitro, and subcutaneous, intrasplenic and orthotopic implanted primary colorectal tumours and their liver metastases/colonies.

Although we know that not all of the expressed isoforms can be detected this way, the overlapping primer pairs we used covered the whole variable region, and provided a simplified pattern (ASP) which could be easily used to follow the possible changes of CD44 spilicing even in more complex in vivo systems. These results proved that, unlike the appearance of new CD44 isoforms during tumorigenesis, no new CD44 isoforms appear during tumour progression from primary tumour to metastasis. Therefore, it was likely that the expression changes of specific variant containing isoforms (as published in the literature) should be rather caused by quantitative changes of a set of isoforms.

Hence, we focused on quantitative expression of two particular exons: v3 and v6. These two exons also appeared to be dominant on our reported qualitative ASP pictures. We separately examined their role in different steps of metastatic cascade in our complex animal experimental model system. Furthermore we managed to gain a glimpse of the role of tumour microenvironment (host) in the modulation of CD44 splice variant expression in conjunction with metastatic potential, as well.

Our isograft model (Balb/C - C26) proved that quantitative changes only happen during real metastasis formation, considering that v3 and v6 expression levels of both orthotopic and heterotopic implanted primary tumours were similar, but increased expression levels were only detected in real liver metastases and not in the colonies. This means that the higher expression level of v3 and v6 is not the effect of the liver microenvironment, but it is the actual pre-existing feature of distinct metastatic cells within the primary tumour. While at orthotopic implantation into large bowel wall tumour cells must undergo each classical steps of metastasis formation (EMT, intravasation, survival in circulation, extravasation, MET, proliferation in metastatic target organ), intrasplenic implantation gives the chance to a proportion of tumour cells to get straingt into the circulation by skipping the early phases of the cascade. Comparison of the two models can potentially differenciate between genes, gene products that act in different in different phases of metastatic process.

The same theory was tested in a human xenograft model as well. HT29 human colorectal adenocarcinoma xenograft showed similar results to the C26 isograft, while both HT25 and HCT116 behaved differently, which proposed further explanation to the contradictions of CD44 literature. We hypothesise that a higher v3/v6 expression level is a necessary, but probably not satisfactory prerequisite of cellular metastatic capability. This is proven by the fact that real liver metastases of all three CRC cell lines expressed v3 and v6 in the same range, despite the different expression levels of their colonic primaries Figure 4A,B. This also means, that the number of cells expressing high levels of CD44v3 and v6 is not necessarily high within the primary tumour, as theoretically a single 'highly expressing' clone is enough for metastasis formation. In a similar experimental model system circulating tumour cells of malignant melanoma were found to express CD44v3 and v6 containing varints on a high level in real metastatic system (RásóBarnett et al. under publication) Correlating this with our result would mean that HT29 had the lowest, while HT25 and HCT116 had the higher percentage of 'highly 
expressing, metastatically potent cells. This also carries the possibility of a primary tumour showing relatively higher expression levels than its metastasis, which would have already been re-selected by the new microenvironment. Translating this into clinical practice would mean, that the 'lack' of overexpression would not exclude metastatic potential or even a worse prognosis. As primary tumour site seemed to be interesting in terms of selection of metastatically potent, CD44v3/v6 high subclones, we tried to find support os this theory in another, quite different model system.

We further examined the role of the primary tumour microenvironment in our subcutaneously implanted xenograft model. CD44v3 and v6 expression levels were different in tumours implanted from the same cell suspension, into genetically identical host, i.e. newborn and adult scid mice, which were only physiologically different. Hence, differences in expression levels of the examined gene products (v3 and v6) could be correlated with differences in metastatic potential (0\% vs. 100\%). Microenvironmental (host) factors (such as maturity immune system, vascular permeability, cytokines and chemokines, etc.) should, therefore, stand as driving factors in the background of metastatically potent subclones which will ultimately determine the clinical behaviour of the entire tumour. These experiments prove that physiological factors of host (as well as primary tumour microenvironment) do matter and in extreme, experimental conditions can fully determine metastatic potential of a malignant system.

\section{Conclusions}

It is likely to assume that tumour microenvironment (tumour host organism) have a central role in metastatic phenotype presentation of primary colorectal cancer.

While normal tissues (such as colonic mucosa) do not express variant isoforms of CD44, tumours seem to perform a wide variation of CD44 isoforms. Presuming that different domains of different CD44 isoforms can perform a variety of new functions, there is no more sense in investigating CD44 "in general".

Moreover, expression pattern of CD44 isoforms was found to be stable, meaning that colorectal type expression profile remained unchanged from tumour cell suspensions (in vitro) throughout primary and metastatic colon cancer xenografts. In contrary, quantitative changes do exist in the expression of distinct variant exons.

CD44 variant isoforms, especially the functionally well-characterized $v 3$ and $v 6$ containing isoforms, seem to massively take part in expressing the metastatic phenotype. Our results support that higher-level v3/v6 co-expression can represent this "quasy-metastatic-gene" function at the primary tumour site and at the early phase of the metastatic cascade. Nontheless, it must be emphasized that only a minor proportion of the primary tumour mass is sufficient to hold "metastatic-phenotype" for the complete primary tumour. Although each colorectal tumour types use metastatic subclones of high CD44v3/v6 expression rate, selective examination of metastatic tumour cell group is not yet resolved. This means that quantitative evaluation of not only CD44 "in general", but even of v3/v6-containing isoforms are inappropriate for the prognosis of metastatic behavior of a single tumour case because of the summative way of the measurement techniques. Moreover this can be the background of the quite diversive results on the predictive value of "CD44" in the literature.

\section{Methods}

\section{Tumour cell cultures}

We maintained cell cultures of three genetically different human colorectal cell lines (HT25 (from M.Hendricks, Iowa), HT29 (ECACC 91072201) and HCT116 (ICLC HTL95025)), four other human neoplastic cell lines (MCF7 - human breast cancer cell line (ATCC HTB-22'), K562 - chronic myelogenous leukemia cell line (ATCC CCL-243"), A431 - human vulvar epidermoid carcinoma cell line (ATCC CRL 1555), HT199 - human malignant melanoma cell line (developed in the 1st Department of Pathology and Experimental Cancer Research (Semmelweis University, Budapest, Hungary)) and a mouse colorectal cell line (C26 - derived from BALB/C Colon26 murine colon adenocarcinoma - obtained from ATCC. USA) in 5\% FCS and 1\% Penicillin/Streptomycin containing 1640 -RPMI medium at $37^{\circ} \mathrm{C}$. For implantation we prepared single-cell suspensions after enzymatic (TripsineEDTA) digestion and washed the cultures twice with FCSfree medium.

\section{In vivo experimental models Isograft model}

We injected suspensions of C26 isograft colorectal tumour cell line into the spleen (4 animals) [80]and colonic wall (4 animals) of adult (20-week-old, $20 \mathrm{~g}-$ weigh) Balb-C mice. Anaesthesia was performed by intraperitoneal injection of Nembuthal $(70 \mathrm{mg} / \mathrm{kg})$. Each tumour injection was performed by $0.05 \mathrm{ml}$ suspension of $5 \times 10^{5}$ cells $\left(10^{7} \mathrm{cell} / \mathrm{ml}\right.$ serum-free one-cell suspensions). After 4 weeks, animals were sacrificed, autopsy was performed and tumour tissues of primary tumours and liver metastases were isolated Figure 5I.a,I.b.

Human xenograft model I. - spontaneous lung metastatic model from heterotopic (subcutaneous) implantation Single cell suspension of HT25, HT29 and HCT116 cell lines $\left(5 \times 10^{5}\right.$ cells / $\left.0.05 \mathrm{ml}\right)$ were subcutaneously implanted into adult and newborn scid mice into the same localization (left lumbar region) using the same 


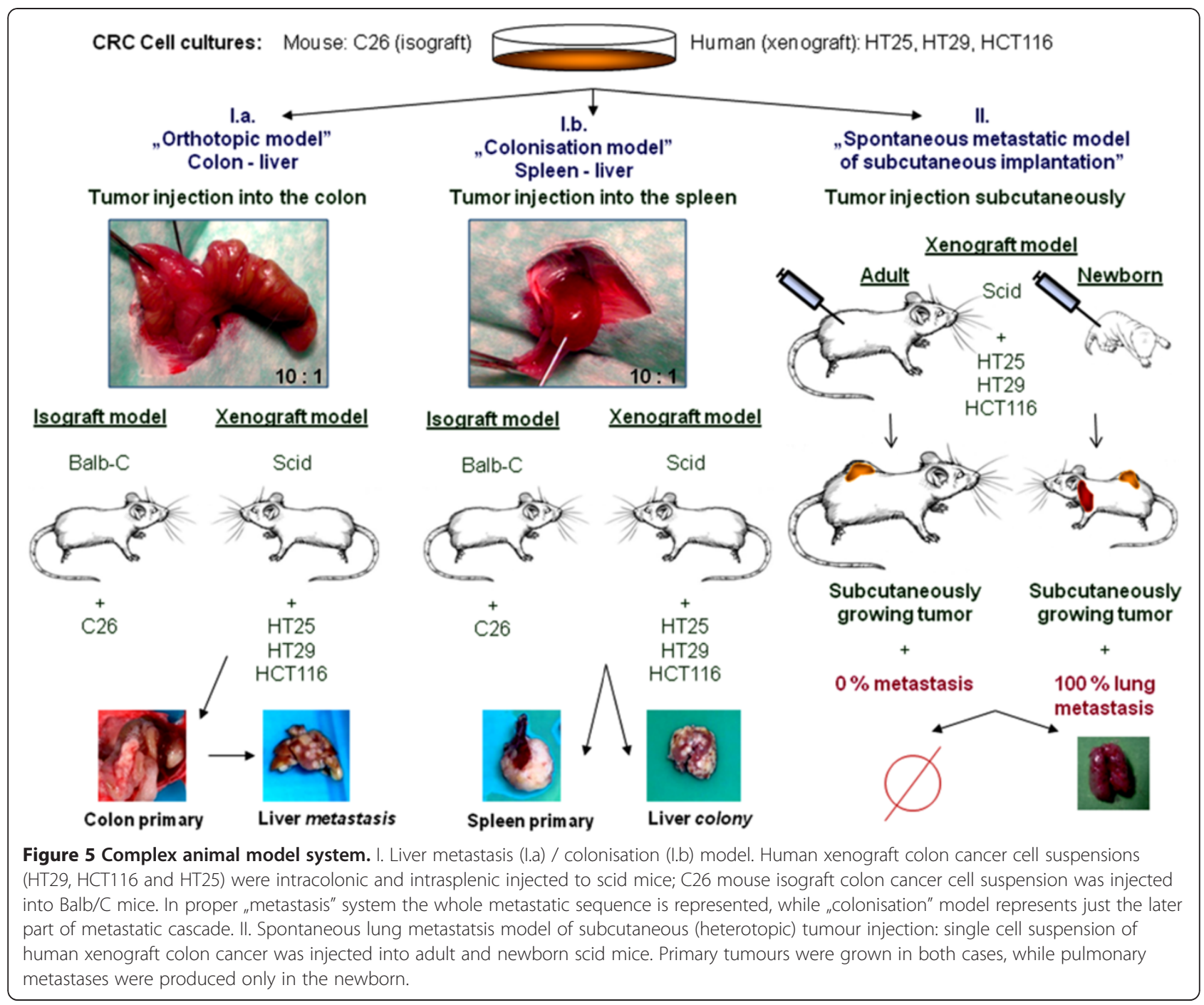

cell suspensions. Both primary and metastatic tumours were dissected from the sacrificed animals after 3 weeks Figure 5II. This model provides particular chance to examine "host" driven changes in the behavior of cancer cell suspensions: while in newbrn mice pulmonary metastases are being formed in each experimental cases, the same cell suspensions are never becoming "metastatic" after implantation into adult mice. The two systems (permissive and non-permissive) were only different in "host age".

Micrometastases were verified on frozen sections of the lung.

\section{Human xenograft model II - Liver-metastasis models from} orthotopic and heterotopic implantation

We performed xenotransplantation of the already mentioned three human colorectal cancer cell lines $\left(5 \times 10^{5}\right.$ cells / $0.05 \mathrm{ml}$ ) into the spleen (heterotopic implantation) and into the colonic wall (orthotopic implantation) of 20-25g-weigh adult scid mice. The operations were performed under intraperitoneal anaesthesia with $70 \mathrm{mg} / \mathrm{kg}$ Nembutal. Animals were sacrificed after 8-10 weeks when obvious signs of cachexia showed (more than $20 \%$ of weight loss of animal occurred). Primary and metastatic tumours were dissected during autopsy Figure 5I.a,I.b.

Samples from primary and metastatic tumours of all three experimental animal models were processed by freezing them immediately after removal for molecular biology.

All animal experiments have been approved by the local Animal Experimental Research Board (TUKEB83/2009).

\section{Total RNA isolation}

Tumour tissue was fronzen in liqued nitrogen and homogenized in mortar prior to RNA isolation. Total RNA was isolated with Trizol $^{\circledR}$ (SIGMA) according to 
manufacturer's instructions. Possible DNA contamination was eliminated with TURBO DNA-free ${ }^{\mathrm{m}}$ (Ambion).

\section{Reverse transcription}

For reverse transcription $1 \mu \mathrm{l}$ of $10 \mathrm{mM}$ dNTP mix $\left(\right.$ Finnzyme ${ }^{\circledR}$ ) and $1 \mu$ l of random nonamer-oligo dT combination for a final concentration of $2.5 \mu \mathrm{M}$ was added to $2 \mu \mathrm{g}$ of purified total RNA. After incubating at $70^{\circ} \mathrm{C}$ for 10 min $2 \mu \mathrm{l}$ of 10x M-MLV Reverse Transcriptase Buffer (Finnzyme ${ }^{\circledR}$ ), $1 \mu \mathrm{l}$ of M-MLV Reverse Transcriptase (200 units/ $\mu \mathrm{l}$, Finnzyme ${ }^{\circledR}$ ), $0.5 \mu \mathrm{l}$ RNase Inhibitor (40 units/ $\mu \mathrm{l}$, Promega ${ }^{\circledR}$ ) and $6.5 \mu \mathrm{l}$ RNAse free water was added for the final volume of $20 \mu \mathrm{l}$ than incubated at $37^{\circ} \mathrm{C}$ for $50 \mathrm{~min}$ and $85^{\circ} \mathrm{C}$ for $10 \mathrm{~min}$.

For checking the occurance of reverse transcription, $\beta$ actin was used as a housekeeping gene ( $\beta$ S1: 5'- TCT GGC ACC ACA CCT TCT AC-3' and BA4: 5'-CTC CTT AAT GTC ACG CAC GAT TTC-3', for murine tumours: MßS1 (RefSeq NM_007393):5'-AGA CAA CAT TGG CAT GGC TT-3', MßA1:5'-AAT GAA GTA TTA AGG CGG AAG ATT-3'), respectively). Under the same PCR conditions, RNA of the same sample was used as negative control for detecting DNA contamination and DEPC treated, RNAse free water as non-template control.

\section{PCR analysis}

For investigation of the variable regions of CD44, serial PCR reactions were carried out with five different human-specific primer pairs (A:Standard 5' : AGT CAC AGA CCT GCC CAA TGC CTT T, B:Standard 3': TTT GCT CCA CCT TCT TGA CTC CCA TG, C:v3 exon 5': GGG AGC CAA ATG AAG AAA ATG AAG ATG AAA G, D:v3 exon 3' : GGT GCC TGT CTC TTT CAT CTT CAT TTT CTT CAT TT, E:v6 exon 3': TCT GTT GCC AAA CCA CTG TTC CTT CTG) [22] Figure 2A.

The PCR reaction mixture contained $2.5 \mu \mathrm{l} 10 \mathrm{X}$ PCR buffer+Mg2+ (DyNazymeTM), $2 \mu \mathrm{l}$ dNTP mix (2.5 mM each), 0.4 $\mu$ l DNA polymerase (DyNazymeTM, $2 \mathrm{U} / \mu \mathrm{l})$, 2.5-2.5 $\mu \mathrm{l}$ of the primers, $2 \mu \mathrm{l}$ of the cDNA and $13.1 \mu \mathrm{l}$ DEPC treated water for the final volume of $25 \mu \mathrm{l}$. The cycling conditions were: $94^{\circ} \mathrm{C}$ for $12 \mathrm{~min}$ once, then $94^{\circ} \mathrm{C}$ for $1 \mathrm{~min}, 65^{\circ} \mathrm{C}$ for $1 \mathrm{~min}, 72^{\circ} \mathrm{C}$ for $1 \mathrm{~min}$ for 40 cycles and the extension step was $72^{\circ} \mathrm{C}$ for $10 \mathrm{~min}$.

PCR products were separated on a $3 \%$ agarose gel and detected with Gel Doc 2000 (Bio-Rad ${ }^{\circledR}$ ) after ethidium bromide staining.

Transcribed isoforms were identified by re-extraction, and direct sequencing (Big Dye Terminator cycle sequencing, Applied Biosystems 3130 Genetic Analyzer) of the distinct bands.

\section{Quantitative PCR analysis}

For quantitative measurement of CD44v3 and v6 variable exons q-PCR reactions were used. Each $25 \mu \mathrm{l}$ reaction mixture contained $12.5 \mu \mathrm{l} 2 \mathrm{X}$ iQ SYBR $^{\circledR}$ Green Supermix (Bio-Rad), 0.5-0.5 $\mu \mathrm{l}$ of each primer for final concentration of $200 \mathrm{nM}$ and $11.5 \mu \mathrm{l}$ of the diluted cDNA. The cycling conditions comprised 3 min of iTaq $^{\mathrm{Tm}}$ DNA polymerase activation at $95^{\circ} \mathrm{C}, 40$ cycles at $95^{\circ} \mathrm{C}$ for $30 \mathrm{sec}, 55^{\circ} \mathrm{C}$ for $30 \mathrm{sec}, 72^{\circ} \mathrm{C}$ for $1 \mathrm{~min}$. Starting quantities were defined on the basis of standard five-fold dilution series (x1-625) carried out with control cDNA of A431 (human squamous cell carcinoma). Relative expression of the examined v3 (primers: CGT CTT CAA ATA CCA TCT CAG CA and ATC TTC ATC ATC AAT GCC TGA) and v6 (primers: GGC AAC TCC TAG TAG TAC AAC G and GTC TTC TCT GGG TGT TTG GC) variable exons were determined by normalizing the starting quantities to the housekeeping $\beta$-actin (primers: GTG GGG CGC CCC AGG CAC CA and CTC CTT AAT GTC ACG CAC GAT TTC) starting quantities from the same cDNA sample.

\section{Next-generation, allele-specific sequencing}

In order to prove identified CD44 isoforms specific to colorectal cancer, next-generation sequencing method was performed. The method briefly is as follows: PCR reaction products from HT29, HT25 and HCT116 human colorectal cell lines (total RNA isolation, purification, reverse transcription as mentioned above) with primer pair A - B (primers designed on 5' and 3' standard region of $\mathrm{CD} 44$ framing the entire variable region, hence theoretically amplifying all the transcribed variant isoforms at the same time) were first amplified, purified with High pure PCR clean-up micro kit (Roche ${ }^{\circledR}$, Mannheim) according to the manufacturer's instructions. The amplicon ends were polished and ligated with roche 454 multiplex identifier (MID) adaptors, so that universal primer binding sites were generated for emulsion PCR. The amplicons were than separated with magnetic ampure beads (Agencourt), non-bound adaptors were eliminated. Emulsion PCR (emPCR) reaction was performed with molarly equivalent amount of sample amplicons according to the manufacturer's protocol (Roche $454^{\circledR}$ ) in modified condition of low A,B primer concentration and slow PCR program to minimalize the amplification efficiency differences between longer and shorter variants. CD44 variant isoform library was clonally amplified with pyrosequencing technique (454 GS Junior, Roche ${ }^{\circledR}$ ), under the condition of $5 \%$ bead-ratio, 200 sequencing cycles, 400 bases read length mode.

Amplicon variant analyzer software (Roche Diagnostics ${ }^{\circledR}$ ) was used to eliminate multiplicity of the samples after MIDs, to trim the primers and to align the reads to the reference cDNA sequence. For easier handling of the huge database of sequenced isoforms of the critically long CD44 molecule, exon-by-exon fishing technique was adapted to identify each amplified exon-combination splice variants. 
Aligment of an exon was accepted to be valid over a threshold of matching rate of $90 \%$. The exon combinations which have more than 50 reads were reported.

Similar process was performed by the four other primer combinations (Primer A-D, A-E, C-B and C-E, respectively. See Figure 2A and Methods above).

\section{Statistical analysis}

Real-time PCR results, relative expression rates (normalized on beta-actin expression rates) were compared with twosample T-tests (data were showing normal distribution). Statistical significance was assumed at $\mathrm{p}<0.05$.

\section{Abbreviations}

ASP: Alternative splice pattern; bp: Base pair; CRC: Colorectal cancer; DEPC: Diethylpyrocarbonate; EDTA: Ethylenediaminetetraacetic acid; ECM: Extracellular matrix; ELFO: Electrophoresis; emPCR: Emulsion polymerase chainreaction; EMT: Epithelial-mesnchymal transition; FCS: Foetal calf serum; MET: Mesenchymal-epithelial transition; NGS: Next-generation sequencing; PCR: Polymerase chainreaction; q-PCR: Quantitative polymerase chainreaction; scid: Severe combined immunodeficiency (mouse).

\section{Competing interests}

There is no competing interest affecting the authors.

\section{Authors' contributions}

BB and LRB designed and described CD44 ASP, complex experimental animal model system was deisgned by $E R$, isograft animal experiments, as well as spontaneous lung metastasis experimets were carried out by BT and $\mathrm{RE}$, while orthotopic and colonization xenograft models were carried out by BB. TB and LRB participated in designing and performing qPCR studies, too. $\mathrm{PB}$ was performing next-generation sequencing on the basis of the experimental design of ER. Statistical assessment, interpretation of result data were led by ER and JT and performed by BB. Direct sequencing was carried out by TB and ER. ER and JT helped in drafting the manuscript. All authors read and approved the final manuscript.

\section{Grant Support}

This study was supported by grants from the TÁMOP-4.2.1./B-09/1/KMR2010-0001 and ETT 087-07/2009.

\section{Acknowledgements}

This is to acknowledge the valuable help in the grammatical and linguistic corrections on the manuscript performed by Matthew Rásó-Barnett and David Borowski.

\section{Author details}

${ }^{1}$ 2nd Institute of Pathology, Semmelweis University, Üllői út 93., 1091, Budapest, Hungary. ${ }^{2}$ St Borbála Hospital, Department of Surgery and Vascular Surgery, Dózsa Gy. út 77., 2800, Tatabánya, Hungary. ${ }^{3}$ Guy's and St. Thomas' Hospital, Westminster Bridge Road, London SE1 7EH, United Kingdom. ${ }^{4}$ Tumour Progression Research Group, Hungarian Academy of Sciences, Budapest, Hungary.

Received: 6 June 2012 Accepted: 12 November 2012

Published: 14 November 2012

\section{References}

1. Parkin DM, Bray F, Ferlay J, Pisani P: Global cancer statistics, 2002. CA Cancer J Clin 2012, 55:74-108.

2. Gryfe R, Swallow C, Bapat B, Redston M, Gallinger S, Couture J: Molecular biology of colorectal cancer. Curr Probl Cancer 2012, 21:233-300.

3. Kim H, Yang XL, Rosada C, Hamilton SR, August JT: CD44 expression in colorectal adenomas is an early event occurring prior to K-ras and p53 gene mutation. Arch Biochem Biophys 1994, 310:504-507.

4. Hao H, Muniz-Medina VM, Mehta H, Thomas NE, Khazak V, Der CJ, Shields JM: Context-dependent roles of mutant B-Raf signaling in melanoma and colorectal carcinoma cell growth. Mol Cancer Ther 2007, 6:2220-2229.

5. Fearon ER, Vogelstein B: A genetic model for colorectal tumorigenesis. Cell 1990, 61:759-767.

6. Djebali S, Davis CA, Merkel A, Dobin A, Lassmann T, Mortazavi A, Tanzer A, Lagarde J, Lin W, Schlesinger F, Xue C, Marinov GK, Khatun J, Williams BA, Zaleski C, Rozowsky J, Röder M, Kokocinski F, Abdelhamid RF, Alioto T, Antoshechkin I, Baer MT, Bar NS, Batut P, Bell K, Bell I, Chakrabortty S, Chen X, Chrast J, Curado J, et al: Landscape of transcription in human cells. Nature 2012, 489:101-108.

7. Lyons AJ, Jones J: Cell adhesion molecules, the extracellular matrix and oral squamous carcinoma. Int J Oral Maxillofac Surg 2007, 36:671-679.

8. Kanke M, Fujii M, Kameyama K, Kanzaki J, Tokumaru Y, Imanishi Y, Tomita T, Matsumura Y: Role of CD44 variant exon 6 in invasion of head and neck squamous cell carcinoma. Arch Otolaryngol Head Neck Surg 2000, 126:1217-1223.

9. Rodrigues LR, Teixeira JA, Schmitt FL, Paulsson M, Lindmark-Mänsson $H$ : The role of osteopontin in tumor progression and metastasis in breast cancer. Cancer Epidemiol Biomarkers Prev 2007, 16:1087-1097.

10. Faleiro-Rodrigues C, Lopes C: E-cadherin, CD44 and CD44v6 in squamous intraepithelial lesions and invasive carcinomas of the uterine cervix: an immunohistochemical study. Pathobiology 2004, 71:329-336.

11. Vihinen PP, Pyrhönen SO, Kähäri V-M: New prognostic factors and developing therapy of cutaneous melanoma. Ann Med 2003, 35:66-78.

12. Ermak G, Jennings $T$, Robinson L, Ross JS, Figge J: Restricted patterns of CD44 variant exon expression in human papillary thyroid carcinoma restricted patterns of CD44 variant exon expression in human papillary thyroid. Cancer Res 1996, 56:1037-1042.

13. Tahara E: Molecular biology of gastric cancer. World J Surg 1995, 19:484-488

14. Wittig BM, Goebel R, Weg-Remers S, Pistorius G, Feifel G, Zeitz M, Stallmach A: Stage-specific alternative cplicing of CD44 and alpha 6 beta 1 integrin in colorectal tumorigenesis. Exp Mol Pathol 2001, 70:96-102.

15. Wielenga VJ, van der Voort R, Taher TE, Smit L, Beuling EA, van Krimpen C, Spaargaren M, Pals ST: Expression of c-Met and heparan-sulfate proteoglycan forms of CD44 in colorectal cancer. Am J Pathol 2000, 157:1563-1573.

16. Yamada $Y$, Itano N, Narimatsu H, Kudo T, Hirohashi S, Ochiai A, Niimi A, Ueda M, Kimata K: Receptor for hyaluronan-mediated motility and CD44 expressions in colon cancer assessed by quantitative analysis using real-time reverse transcriptase-polymerase chain reaction. Jpn j cancer res 1999, 90:987-992.

17. Aruffo A, Stamenkovic I, Melnick M, Underhill CB, Seed B: CD44 is the principal cell surface receptor for. Cell 1990, 61:1303-1313.

18. van Royen N, Voskuil M, Hoefer I, Jost M, de Graaf S, Hedwig F, Andert J-P, Wormhoudt TaM, Hua J, Hartmann S, Bode C, Buschmann I, Schaper W, van der Neut R, Piek JJ, Pals ST: CD44 regulates arteriogenesis in mice and is differentially expressed in patients with poor and good collateralization. Circulation 2004, 109:1647-1652.

19. Brennan FR, Mikecz K, Glant TT, Jobanputra P, Pinder S, Bavington C, Morrison P, Nuki G: CD44 expression by leucocytes in rheumatoid arthritis and modulation by specific antibody: implications for lymphocyte adhesion to endothelial cells and synoviocytes in vitro. Scand J Immunol 1997, 45:213-220.

20. Kitano A, Oshitani N, Matsumoto T, Kobayashi K: Display Settings: CD44 variants in ulcerative colitis and Crohn 's disease. Lancet 1996, 348:266-267.

21. Teder P, Vandivier RW, Jiang D, Liang J, Cohn L, Puré E, Henson PM, Noble PW: Resolution of lung inflammation by CD44. Science 2002, 296:155-158.

22. Givehchian M, Woerner SM, Lacroix J, Zöller M, Drings P, Becker H, Kayser K, Ridder R, von Knebel Doeberitz M: Expression of CD44 splice variants in normal respiratory epithelium and bronchial carcinomas: no evidence for altered CD44 splicing in metastasis. Oncogene 1996, 12:1137-1144.

23. Grimme HU, Termeer CC, Bennett KL, Weiss JM, Schöpf E, Aruffo A, Simon JC: Colocalization of basic fibroblast growth factor and CD44 isoforms containing the variably spliced exon v3 (CD44v3) in normal skin and in epidermal skin cancers. Br J Dermatol 1999, 141:824-832.

24. Isabel Fonseca JFMN JS: Expression of CD44 isoforms in normal salivary gland tissue: an immunohistochemical and ultrastructural study. Histochem Cell Biol 2000, 114:5-6.

25. Fox SB, Fawcett J, Jackson DG, Collins I, Gatter KC, Harris AL, Gearing A, Simmons DL: Normal human tissues, in addition to some tumors, express 
multiple different CD44 isoforms normal human tissues, in addition to some tumors, express multiple. Cancer Res 1994, 54:4539-4546.

26. Woerner SM, Givehchian M, Dürst M, Schneider A, Costa S, Melsheimer $P$ Lacroix J, Zöller M, Doeberitz MK: Expression of CD44 splice variants in normal, dysplastic, and neoplastic cervical epithelium. Clin Cancer Res 1995, 1:1125-1132.

27. Levin TG, Powell AE, Davies PS, Silk AD, Dismuke AD, Anderson EC, Swain JR, Wong MH: Characterization of the intestinal cancer stem cell marker CD166 in the human and mouse gastrointestinal tract. Gastroenterology 2010, 139:2072-2082.e5.

28. Zeilstra J, Joosten SPJ, Dokter M, Verwiel E, Spaargaren M, Pals ST: Deletion of the WNT target and cancer stem cell marker CD44 in Apc(Min/+) mice attenuates intestinal tumorigenesis. Cancer Res 2008, 68:3655-3661.

29. Vaiopoulos AG, Kostakis ID, Koutsilieris M, Papavassiliou AG: Colorectal cancer stem cells. Stem cells 2012, 30:363-371.

30. Asao T, Nakamura J, Shitara Y, Tsutsumi S, Mochiki E, Shimura T, Takenoshita S, Kuwano H: Loss of standard type of CD44 expression in invaded area as a good indicator of lymph-node metastasis in colorectal carcinoma. Dis Colon Rectum 2000, 43:1250-1254. discussion 1254-5.

31. Wielenga VJM, Heider K, Johan G, Progression T, Offerhaus GJA, Adolf G, Berg FMVD, Punta H, Herlich P, Pals ST: Expression of CD44 variant proteins in human colorectal cancer is related to tumor progression advances in brief expression of CD44 variant proteins in human colorectal cancer is related to. Cancer Res 1993, 53:4754-4756.

32. Zhu J, He J, Liu Y, Simeone DM, Lubman DM: Identification of glycoprotein markers for pancreatic cancer CD24+CD44+ stem-like cells using nano-LC-MS/MS and tissue microarray. J Proteome Res 2012, 11:22722281.

33. Dalerba P, Dylla SJ, Park I-K, Liu R, Wang X, Cho RW, Hoey T, Gurney A, Huang EH, Simeone DM, Shelton AA, Parmiani G, Castelli C, Clarke MF: Phenotypic characterization of human colorectal cancer stem cells. Proc Natl Acad Sci U S A 2007, 104:10158-10163.

34. Alderton G: Tumour stem cells: generating colon cancer. Nat Rev Cancer 2006, 6:906-907.

35. Fillmore C, Kuperwasser C: Human breast cancer stem cell markers CD44 and CD24: enriching for cells with functional properties in mice or in man? Breast Cancer Res 2007, 9:303.

36. Takaishi S, Okumura T, Tu S, Wang SSW, Shibata W, Vigneshwaran R, Shanisha AK, Gordon SA, Shimada Y, Wang TC: Identification of Gastric Cancer Stem Cells Using the Cell Surface Marker CD44. Stem Cells 2009, 27:1006-1020.

37. Li C, Heidt DG, Dalerba P, Burant CF, Zhang L, Adsay V, Wicha M, Clarke MF, Simeone DM: Identification of pancreatic cancer stem cells. Cancer Res 2007, 67:1030-1037.

38. Koukourakis MI, Giatromanolaki A, Tsakmaki V, Danielidis V, Sivridis E: Cancer stem cell phenotype relates to radio-chemotherapy outcome in locally advanced squamous cell head-neck cancer. Br J Cancer 2012, 106:846-853.

39. Hu Y, Fu L: Targeting cancer stem cells: a new therapy to cure cancer patients. Am J Cancer Res 2012, 2:340-356.

40. Tumor M, Lilly P, Bourguignon W: CD44 in Cancer Progression: adhesion. Migration and Growth Regul 2004, 35:211-231.

41. Kuhn $S$, Koch $M$, Nübel $T$, Ladwein $M$, Antolovic $D$, Klingbeil $P$, Hildebrand D, Moldenhauer G, Langbein L, Franke WW, Weitz J, Zöller M: A complex of EpCAM, claudin-7, CD44 variant isoforms, and tetraspanins promotes colorectal cancer progression. Mol Cancer Res 2007, 5:553-567.

42. Ngan CY, Yamamoto H, Seshimo I, Ezumi K, Terayama M, Hemmi H, Takemasa I, Ikeda M, Sekimoto M, Monden M: A multivariate analysis of adhesion molecules expression in assessment of colorectal cancer. J Surg Oncol 2007, 95:652-662.

43. Camp RL, Kraus TA, Puré E: Variations in the cytoskeletal interaction and posttranslational modification of the CD44 homing receptor in macrophages. J Cell Biol 1991, 115:1283-1292.

44. Bendardaf R, Algars A, Elzagheid A, Korkeila E, Ristamäki R, Lamlum H, Collan Y, Syriänen K, Pyrhönen S: Comparison of CD44 expression in primary tumours and metastases of colorectal cancer. Oncol Rep 2006 16:741-746.

45. Marhaba R, Zöller M: CD44 in cancer progression: adhesion, migration and growth regulation. J Mol Histol 2004, 35:211-231.

46. Fujisaki T, Tanaka Y, Fujii K: CD44 stimulation induces integrin-mediated adhesion of colon cancer cell lines to endothelial cells by up-regulation of integrins and c-met and activation of integrins CD44 stimulation induces integrin-mediated adhesion of colon cancer cell lines. Cancer Res 1999, 59:4427-4434.

47. Ghatak S, Misra S, Toole BP: Hyaluronan oligosaccharides inhibit anchorage-independent growth of tumor cells by suppressing the phosphoinositide 3-kinase/Akt cell survival pathway. J Biol Chem 2002, 277:38013-38020

48. Kuniyasu H, Oue N, Tsutsumi M, Tahara E, Yasui W: Heparan sulfate enhances invasion by human colon carcinoma cell lines through expression of CD44 variant exon 3. Clin Cancer Res 2001, 7:4067-4072.

49. Ohashi R, Takahashi F, Cui R, Yoshioka M, Gu T, Sasaki S, Tominaga S, Nishio K, Tanabe KK, Takahashi K: Interaction between CD44 and hyaluronate induces chemoresistance in non-small cell lung cancer cell. Cancer Lett 2007, 252:225-234.

50. Klingbeil P, Marhaba R, Jung T, Kirmse R, Ludwig T, Zöller M: CD44 variant isoforms promote metastasis formation by a tumor cell-matrix cross-talk that supports adhesion and apoptosis resistance. Mol Cancer Res 2009, 7:168-179.

51. Goodison S, Urquidi V, Tarin D: CD44 cell adhesion molecules. Mol Pathol 1999, 52:189-196.

52. Sneath RJ, Mangham DC: The normal structure and function of CD44 and its role in neoplasia. Mol Pathol 1998, 51:191-200.

53. Naor D, Nedvetzki S, Golan I, Melnik LFY: Display Settings: CD44 in cancer. Crit Rev Clin Lab Sci 2002, 39:527-579.

54. Naor D, Sionov RV, Ish-Shalom D: CD44: structure, function, and association with the malignant process. Adv Cancer Res 1997, 71:241-319.

55. Skotheim Rl, Nees M: Alternative splicing in cancer: noise, functional, or systematic? Int J Biochem Cell Biol 2007, 39:1432-1449.

56. Zalewski B: Levels of $v 5$ and v6 CD44 splice variants in serum of patients with colorectal cancer are not correlated with pT stage, histopathological grade of malignancy and clinical features. World J Gastroenterol 2004, 10:583-585.

57. Zalewski B, Stasiak-Barmuta A, Sulkowski S, Piotrowski Z, Myśliwiec P, Kukliński A: Glycoprotein CD44 variant 4 expression in tumour epithelial cells of patients with colorectal cancer. Rocz Akad Med Bialymst 2004, 49(Suppl 1):37-39.

58. Weg-Remers $\mathrm{S}$, Anders $\mathrm{M}$, von Lampe B, Riecken EO, Schüder G, Feifel G, Zeitz M, Stallmach A: Decreased expression of CD44 splicing variants in advanced colorectal carcinomas. Eur J Cancer 1998, 34:1607-1611.

59. Gutt CN, Kim Z-G, Schemmer P, Krähenbühl L, Schmedt C-G: Impact of laparoscopic and conventional surgery on Kupffer cells, tumorassociated CD44 expression, and intrahepatic tumor spread. Arch Surg 2002, 137:1408-1412.

60. Bennett KL, Jackson DG, Simon JC, Tanczos E, Peach R, Modrell B, Stamenkovic I, Plowman G, Aruffo A: CD44 isoforms containing exon V3 are responsible for the presentation of heparin-binding growth factor. J Cell Biol 1995, 128:687-698.

61. Spix Julie K, Chay Edward Y, Block Ethan RKJK: Hepatocyte growth factor induces epithelial cell motility through transactivation of the epidermal growth factor receptor. Exp Cell Res 2007, 313:3319-3325.

62. Orian-rousseau V, Chen L, Sleeman JP, Herrlich P, Ponta H: CD44 is required for two consecutive steps in HGF / c-Met signaling. Genes Dev 2002, 16:3074-3086.

63. Cheng C, Yaffe MB, Sharp PA: A positive feedback loop couples Ras activation and CD44 alternative splicing. Genes Dev 2006, 20:1715-1720.

64. Hofmann M, Rudy W, Günthert U, Giinthert U, Zimmer SG, Zawadzki V, Zã M, Lichtner RB, Herrlich P, Ponta H: A link between ras and metastatic mehavior of tumor cells: ras induces CD44 promoter activity and leads to low-level expression of metastasis-specific variants of CD44 in CREF cells. Cancer Res 1993, 53:1516-1521.

65. Reeder JA, Gotley DC, Walsh MD, Fawcett J, Antalis TM: Expression of antisense CD44 variant 6 inhibits colorectal tumor metastasis and tumor growth in a wound environment expression of antisense CD44 variant 6 inhibits colorectal tumor metastasis and tumor growth in a wound environment1. Cancer Res 1998, 58:3719-3726.

66. Haruyama K, Matsumura Y, Moriya Y, Kakizoe T, Ochiai A, Kawaguchi MST: Clinicopathological significance of the expression of CD44v2 in colorectal cancer. Anticancer Res 1999, 19:4421-4428.

67. Barbour AP, Reeder JA, Walsh MD, Fawcett J, Antalis TM, Gotley DC: Expression of the CD44v2-10 isoform confers a metastatic phenotype: importance of the heparan sulfate attachment site CD44v3. Cancer Res 2003, 63:887-892. 
68. Ropponen KM, Eskelinen MJ, Lipponen PK, Alhava E, Kosma VM: Expression of CD44 and variant proteins in human colorectal cancer and its relevance for prognosis. Scand J Gastroenterol 1998, 33:301-309.

69. Yamada Y, Itano N, Narimatsu H, Kudo T, Hirohashi S, Ochiai A, Tohnai I, Ueda M, Kimata K: CD44 variant exon 6 expressions in colon cancer assessed by quantitative analysis using real time reverse transcriptasepolymerase chain reaction. Oncol Rep 2003, 10:1919-1924.

70. Dong W-G, Sun X-M, Yu B-P, Luo H-S, Yu J-P: Role of VEGF and CD44v6 in differentiating benign from malignant ascites. World I Gastroenterol 2003, 9:2596-2600.

71. Morrin MDP: CD44v6 is not relevant in colorectal tumour. Int J Colorectal Dis 2002, 17:30-36.

72. van Weering DH, Baas PD, Bos JL: A PCR-based method for the analysis of human CD44 splice products. PCR Methods App/ 1993, 3:100-106

73. Heider K, Dämmrich J, Skroch-angel P, Herrlich P, Ponta H: Differential expression of CD44 splice variants in intestinal- and diffuse-type human gastric carcinomas and normal gastric mucosa differential expression of CD44 splice variants in intestinal- and diffuse-type human gastric carcinomas and normal gastric. Cancer Res 1993, 53:4197-4203.

74. Muthukumaran N, Miletti-González KE, Ravindranath AK, Rodríguez-Rodríguez L: Tumor necrosis factor-alpha differentially modulates CD44 expression in ovarian cancer cells. Mol Cancer Res 2006, 4:511-520

75. Shin C, Manley JL: Cell signalling and the control of pre-mRNA splicing. Nat Rev Mol Cell Biol 2004, 5:727-738.

76. Gotley DC, Fawcett J, Walsh MD, Reeder JA, Simmons DL, Antalis TM: Alternatively spliced variants of the cell adhesion molecule CD44 and tumour progression in colorectal cancer. Br J Cancer 1996, 74:342-351.

77. Khoursheed M, Mathew TC, Makar RR, Sonia L, Abul H, Asfar S, Al-Sayer H, Dashti HM, Al-Bader A: Expression of CD44s in human colorectal cancer. Pathol Oncol Res 2002, 8:170-174.

78. Rudzki Z, LeDuy L, Jothy S: Changes in CD44 expression during carcinogenesis of the mouse colon. Exp Mol Pathol 1997, 64:114-125.

79. Furuta K, Zahurak M, Yang XL, Rosada C, Goodman SN, August JT, Hamilton SR: Relationship between CD44 expression and cell proliferation in epithelium and stroma of colorectal neoplasms. Am 」 Pathol 1996, 149:1147-1155.

80. Paku S, Lapis K: Morphological aspects of angiogenesis in experimental liver metastases. Am J Pathol 1993, 143:926-936.

doi:10.1186/1476-4598-11-83

Cite this article as: Bánky et al:: Characteristics of CD44 alternative splice pattern in the course of human colorectal adenocarcinoma progression. Molecular Cancer 2012 11:83.

\section{Submit your next manuscript to BioMed Central and take full advantage of:}

- Convenient online submission

- Thorough peer review

- No space constraints or color figure charges

- Immediate publication on acceptance

- Inclusion in PubMed, CAS, Scopus and Google Scholar

- Research which is freely available for redistribution 